\title{
МЕДИЧНІ ТЕРМІНИ IЗ СОМАТИЧНИМИ КОМПОНЕНТАМИ КЕФАЛ-, МЕДУЛ(О)-, МЕНІН-, МЕНІН(О)- У СУЧАСНІЙ УКРАЇНСЬКІЙ МОВІ
}

\author{
ГАЛИНА ГЕРМАНОВИЧ \\ Львівський національний університет імені Івана Франка, Львів - Україна \\ germanovich_galina@i.ua; ORCID: 0000-0001-9021-9337 \\ TERMINY MEDYCZNE Z SOMATYCZNYMI KOMPONENTAMI \\ CEPHAL-, MEDUL(O) -, MENIN-, MENING(O)- \\ WE WSPÓŁCZESNYM JĘZYKU UKRAIŃSKIM \\ HAEYNA HERMANOWYCZ \\ Lwowski Uniwersytet Narodowy imienia Iwana Franki, Lwów - Ukraina
}

STRESZCZENIE. W artykule opisano terminy medyczne z komponentami cephal-, medul (o)-, menin-, mening (o)- w języku ukraińskim. Zwrócono uwagę na kwestię wymiany analizowanych leksemów. Dostrzeżono ich wydajność oraz mobilność słowotwórczą. Wskazano perspektywy dalszych badań, albowiem terminy z komponentami somatycznymi wymagają prześledzenia ich wydajności i mobilności.

Słowa kluczowe: język ukraiński, terminy medyczne z komponentami somatycznymi, grupy leksykalno-semantyczne, relacja paradygmatyczna, wydajność.

\author{
MEDICAL TERMS WITH \\ CEPHAL-, MEDUL(O)-, MENIN-, MENING(O)- \\ SOMATIC COMPONENTS \\ IN MODERN UKRAINIAN LANGUAGE \\ HALYNA HERMANOVICH \\ Ivan Franko Lviv National University, Lviv — Ukraine
}

ABSTRACT. Ukrainian medical terms-composites with international components cephal-, medul(o)-, menin-, mening (o)- have been analyzed in the article. The problem of their interchange with the Ukrainian equivalents has been brought up. Their productivity and word formation mobility have been defined. The prospect of this research is that terms with the somatic components require studying of their productivity and mobility.

Key words: Ukrainian, medical somatic terms-composites, lexico-semantic groups, paradigmatic relations, productivity.

П

роблеми творення та вживання медичних термінів були, є й залишаються актуальними, оскільки більшість спеціальних одиниць - iншомовні, зазвичай походять $з$ латинської та грецької мов. Наприкінці XX - поч. XXI ст. іншомовні компоненти в українському мовознавстві розглядали В. Акуленко, С. Карпіловська, Н. Клименко, Н. Кобзар, І. Кочан, О. Пономарів та інші вчені. Зокрема, І. Кочан опрацювала терміни з міжнародними соматичними компонентами, розглянула їхню фіксацію в словниках, окремі лексико-тематичні групи, сферу вживання, поєднання з іншими коренями (осно- 
вами), можливість заміни національними відповідниками ${ }^{1}$; Н. Кочукова вивчала терміни з компонентом нео- в українській науковій мові, розглядала специфіку цього компонента, з'ясувала його продуктивність, особливості поєднання із запозиченими й питомими лексемами ${ }^{2}$. Детально описували українську медичну термінологію Ю. Бражук, О. Вікторіна, Н. Гимер, Г. Дидик-Меуш, М. Дмитрук, Г. Золотухін, І. Іваненко, В. Калько, Т. Лепеха, Н. Литвиненко, Т. Луковенко, Н. Місник, Л. Пиріг, Д. Сизонов, Л. Симоненко, О. Стрижаковська, Т. Файчук, Н. Цісар та ін. Напр., Т. Луковенко працювала над українською гомеопатичною лексикою, О. Стрижаковська досліджувала назви хвороб у буковинських говірках ${ }^{4}$, В. Тихоша вивчала семантичні особливості медичних термінів української мови, Г. Навчук й А. Ткач звернули увагу на проблеми впорядкування української медичної термінології на сучасному етапі 6 .

Основою професійного мовлення медика $є$ вживання фахових термінів високого рівня стандартизації. Аналізуючи лексичний склад фахового мовлення медика, виявлено, що велика кількість українських компонентів ще не була в полі зору дослідників. Медична лексика є однією з найдавніших терміносистем. Вона формувалася як на світовій, так і на власній мовних основах. Розвиток і вдосконалення медичної термінології можна простежувати через наукові праці, фахові посібники та підручники, медичні словники.

У цій статті звернемо увагу на те, чи відповідають медичні терміни з міжнародними компонентами кефал-, медул(о)-, менін-, менінг(o)- таким вимогам термінологічної норми, як: 1) співвіднесення терміна 3 поняттям; 2) однозначність терміна в межах певної термінологічної системи; 3) точність терміна; 4) нейтральність; 5) системність; 6) наявність чіткої дефініції; 7) короткість (стислість) у плані вираження; 8) відсутність синонімів чи омонімів у межах однісї терміносистеми; 9) доброзвучність і словотвірна мобільність; 10) нормативність, тобто відповідність нормам сучасної літературної мови ${ }^{7}$.

Мета статті - схарактеризувати українські медичні терміни-композити 3 міжнародними компонентами кефал-, медул(о)-, менін-, менінг(о)- за лексико-семантичними групами та парадигматичними відношеннями; виявити їхню словотвірну мобільність у сучасній українській літературній мові. Об'єкт дослідження - медичні терміни-композити із соматичними компонентами. Предмет - їхні лексико-семантичні ознаки, особливості термінів із запозиченими та національними компонентами. Матеріал вилучено методом суцільної вибірки з Медичного ілюстрованого словника Дорланда (2007), Украйнсько-

${ }^{1}$ I. М. Кочан, Терміни з міжнародними соматичними компонентами в сучасній українській мові, [в:] „Мова. Культура. Взаєморозуміння”, зб. наук. праць, за наук. ред. Т. Ко с мед и, Дрогобич 2012, вип. 2, с. 169-179.

${ }^{2}$ Н. І. Кочуков а, Терміни з компонентом нео- в украӥнській науковій мові, [в:] „Наукові записки Національного університету «Острозька академія», сер. «Філологічна»”, 2014, вип. 49, c. $55-57$.

3 Т. О. Луковенко, Українська гомеопатична лексика, автореф. дис. ... канд. філол. наук, Донецьк 2011.

${ }^{4}$ О. С. С три жаковська, Назви хвороб у буковинських говірках, автореф. дис. ... канд. філол. наук, Івано-Франківськ 2011.

5 В. I. Тихоша, Структурно-семантичні особливості медичних термінів украӥнської мови, [в:] „Філологічні науки”, зб. наук. праць, Херсон 2003, вип. 20, с. 100-104.

${ }^{6}$ Г. В. Навчук, А. В. Ткач, Українська медична термінологія на сучасному етапі: проблеми впорядкування, [в:] Електронний ресурc: https:/www.bsmu.edu.ua/files/BMV/BMV-2010-1404(56)/BMV-2010-14-04(56)-163.pdf (12.02.2018).

7 I. М. Кочан, Украӥнська наукова лексика: міжнародні компоненти в термінологї, навч. посіб., Київ 2013, с. 57-58. 
латинсько-англійського тлумачного словника М. Павловського, Л. Петрух, І. Головко (1995), Тлумачного словника медичних термінів Н. Литвиненко, Н. Мicник (2010), Нового словника іншомовних слів Л. Шевченко, О. Ніки, О. Хом'як, А. Дем'янюк (2008) та Словника чужсослів П. Штепи (1977).

Сома (грец. sота - тіло): "1) тіло на відміну від психіки; 2) тканина тіла на відміну від зародкових клітин; 3) тіло тканини"в. У Новому словнику іншомовних слів термін “сома” має два значення: “1) (гр. soта = тіло) - мед. тіло організму, крім материнських клітин спор у рослин і клітин зародкового шляху або статевих клітин у тварин; термін увів німецький біолог А. Вейсман; 2) (д.-інд. syma - у давньоіндійській міфології - божественний галюцинований напій (сік) і божество цього напою, що відігравав важливу роль в обрядах жертвоприношень”. Окремо виділяють сомато- (гр. soma-atos = тіло) - у складних словах позначає "тілесний”".

Актуальність дослідження термінів із соматичними компонентами зумовлена необхідністю встановлення специфіки соматичного символу в термінікомпозиті та визначення лексико-синтаксичних особливостей слів 3 такими компонентами.

На сучасному етапі в українській медичній мові існують терміни, що складаються 3 міжнародних терміноелементів грецького, латинського чи українського походження. Лексеми із соматичними компонентами $\epsilon$ лише в медичній галузі. До соматичних міжнародних компонентів належать: карді(о)-, гем(o)-, гемат (o), om(o)-, офтальм(o)-, псих(o)- та ін. В українській мові наявні такі відповідники: серце, кров, вухо, око, голова та ін. Серед соматичних компонентів уживають і застарілі слова, напр.: вуста, чоло, перст.

Розглянемо лексеми з міжнародними компонентами кефал-, медул(о)-, менін-, менінг(o)-, що належать до українських соматичних понять голова та мозок.

Голова (caput /визн. 1/, head /визн. 2/ /англо-сакс. heafod/) - 1) верхня ділянка тіла, що складається з мозкової та лицевої частини. Містить головний мозок, органи спеціального чуття, початкові відділи травної і дихальної систем; 2 ) верхня, передня або проксимальна частина структури або тіла ${ }^{10}$. Найбільше лексем (9) із цим компонентом зафіксовано в Медичному ілюстрованому словнику Дорланда. Соматичний компонент голова зазвичай $є$ частиною складених медичних термінів, напр.: баштоподібна голова, велика голова, квадратна голова, комічна голова, сідлоподібна голова, голова у формі піскового годинника. Зауважимо, що не завжди компонент голова вживається як соматичний. Напр., біла голова - “південноафр. назва праці"”1, голова медузи - “розширені підшкірні вени навколо пупка". Ін. назва "голова Медузи"'2. Решта термінів (3) із соматичним компонентом голова належать до групи “такий, що стосується органа, його захворювання": головно-хребтовий, голово-грудний, (напр., головоногий - “такий, що стосується голови й ноги") ${ }^{13}$. Усі інші терміни, що у своєму складі мають компонент голова, належать до другого визначення, напр.:

${ }^{8}$ Украйнсько-англійський ілюстрований медичний словник Дорланда (перев. 30-го, америк. вид-ня), у 2 томах, Львів 2007, т. 2, с. 1679.

9 Л. І. Шевченко, О. І. Ніка, О. І. Хом'як, А. А. Дем'янюк, Новий словник іншомовних слів, за ред. Л. І. Шевчен ко, Київ 2008, с. 570.

${ }^{10}$ Украӥнсько-англійський ілюстрований медичний словник Дорланда..., т. 1, с. 445.

${ }^{11}$ Там само.

${ }^{12}$ Там само.

${ }^{13}$ Там само, т. 1, с. 447. 
головковий, головневі, головний, головчастий — “такий, що стосується головки або головочки кістки"14.

Мозок (marrow /визн. 3, 4/; medulla /визн. 1-3/ р. в. і мн. Medullae /лат./) “1) загальна назва найбільш внутрішньої частини органа або структури; 2) довгастий мозок; 3) кістковий мозок; 4) будь-яка ін. м'яка речовина, подібна до кісткового мозку"15. У Медичному ілюстрованому словнику Дорланда зафіксовано 22 складені терміни, що містять лексему мозок (напр., великий мозок, головний мозок, дихальний головний мозок, жселатинозний кістковий мозок, нюховий мозок, передній мозок, спинний мозок та ін.), а також 6 термінів із соматичним компонентом мозок належать до групи “такий, що стосується органа" (мозковий, мозково-мозочковий, мозково-мостовий, мозково-очний, мозкоподібний /напр., мозково-сухожилковий - "такий, що стосується головного мозку та сухожилків"16/).

У Тлумачному словнику медичних термінів Н. Литвиненко, Н. Місник зафіксовано кефал-. Це частина складних слів, яка означає “такий, що стосується голови" "17, тому це соматичний компонент. У словнику налічується 4 лексеми, що позначають: 1) процеси: кефалографія - "графічна реєстрація коливань голови відносно вертикальної осі тіла; запис рухів голови; метод вивчення механізмів збереження пози стояння; рентгенографія голови" "8; кефалометрія — “вимірювання голови градуйованим циркулем; в антропології: вимірювання черепа" 19 ; 2) назва захворювання: кефалгематома - "крововилив під окістя склепіння черепа, переважно в новонароджених; внутрішня кровотеча" 20 ; 3) назва приладу: кефалокраміокласт - "акушерський інструмент для витягання плода за перфоровану голівку"21. Ці медичні терміни відсутні в Медичному ілюстрованому словнику Дорланда, але в Новому словнику іншомовних слів, який уклали Л. Шевченко, О. Ніка, О. Хом'як, А. Дем'янюк, зафіксовано медичний термін кефалометрія з тим самим значенням.

Медуло- - частина складних слів, що вказує на відношення до кісткового мозку або мозку 22. У Медичному ілюстрованому словнику Дорланда з компонентами медуло- виявлено 10 термінів, серед яких - 5 лексем указують на відношення до мозку. Вони позначають: 1) назви захворювання: медулобласто$\boldsymbol{м a}$ - "злоякісна, дуже чутлива до радіоопромінення пухлина мозочка, утворена недиференційованими нейрогліальними клітинами"23; медулоепітеліома - "рідкісний різновид нейроепітеліальних пухлин, що здебільшого зустрічаються в головному мозку чи сітківці” 24; 2) “такий, що стосується органа, його захворювання або діє на нього": медулярний - 1) “такий, що стосується мозку”; 2) “такий, що стосується кісткового мозку”; 3) “такий, що стосується спинного мозку”. Ін. назва мієлоїднийег; медуляція - “1) мієлінізація; 2) мієлопоез;

${ }^{14}$ Там само.

15 Там само, т. 1, с. 1084.

${ }^{16}$ Там само.

${ }^{17}$ Н. П. Литвиненко, Н.В.Місник, Тлумачний словник медичних термінів: російською, латинською та українською мовами, Київ 2010, с. 314.

18 Там само.

19 Там само.

${ }^{20}$ Там само.

21 Там с амо.

${ }^{22}$ Украӥнсько-англійський ілюстрований медичний словник Дорланда..., т. 1, с. 1018.

23 Там само.

${ }^{24}$ Tам само.

${ }^{25}$ Tам само. 
3) утворення кісткового мозку, довгастого мозку, мозкового шару"26; 3) клітина: медулобласт - "недиференційована клітина ембріонального мозку або нервової трубки". Може розвинутися в нейробласт або спонгіобласт ${ }^{27}$. У Тлумачному словнику медичних термінів Н. Литвиненко, Н. Місник таких лексем 2, напр., медулобластома, медулоепітеліома.

Менін-, менінг(o)- - частина складних слів, що вказує на зв'язок з оболонкою, зокрема мозковою ${ }^{28}$. Найбільше лексем із цими соматичним компонентами зафіксовано в Медичному ілюстрованому словнику Дорланда - 33. Тлумачний словник медичних термінів (укладачі Н. Литвиненко, Н. Місник) налічує 19 слів. У Новому словнику іншомовних слів, який уклали Л. Шевченко, О. Ніка, О. Хом'як, А. Дем'янюк (2008), зазначено 3 лексеми із частинами менін-, менінг(о)-, напр.: менінгіт, менінгококи, менінгоенцефаліт ${ }^{29}$. Медичних термінів, що вказують на зв'язок зі спинним мозком, налічується 4, напр., менінгомієліт, менінгомієлорадикуліт, менінгоостеофлебіт, менінгоцеле "грижоподібне випинання мозкових оболонок через дефект кістки"зо.

Усі слова із компонентами менін-, менінг(о)- позначають: 1) процеси: менінгомаляція - "розм'якшення оболонки"31; 2) назви захворювання: менінгеоматоз, менінгізм, менінгіома, менінгоартеріїт, менінгогематома, менінгоениефаліт, менінгоецефаломієліт, менінгоенцефаломієлопатія, менінгоз, менінгококоз, менінгопатія, менінгорагія та інші (напр., менінгіт - "запалення мозкових оболонок, як правило, бактеріальне /бактеріальний менінгіт/ чи вірусне /вірусний менінгіт/"з2; менінгопневмоніт - "хвороба, що спричиняється в лабораторних тварин введенням етіологічного чинника пситтакозу"). Для неї характерні гострий менінгіт і пневмоніт ${ }^{33}$; 3) “такий, що стосується органа, його захворювання або діє на нього": менінгеальний, менінгітний, менінгогенний, менінгокірковий та інші (напр., менінгорадикулярний - “такий, що стосується мозкових оболонок і корінців черепних та спинномозкових нервів" 34 ; менінговаскулярний - “оболонково-судинний" $\left.{ }^{35}\right)$; 4) вид: менінгокок - "окремий мікроорганізм виду Neisseria meningitides" ${ }^{36}$.

Терміни менінгіома, менінгіт, менінгоенцефаліт, менінгоенцефаломісліт, менінгококцемія є частиною складених медичних термінів, зокрема: ангіобласна менінгіома, кісткова менінгіома, наметова менінгіома, асептичний менінгіт, базальний менінгіт, внутрішній менінгіт, еозинофільний менінгоенцефаліт, первинний амебний менінгоенцефаліт, гранульоматозний менінгоениефаломієліт, гостра блискавична менінгококцемія та інші (налічуємо 62 одиниці $)^{37}$.

Полісемія зафіксована в таких словах: кефалографія - "графічна реєстрація коливань голови відносно вертикальної осі тіла; запис рухів голови; метод

26 Там само.

27 Там само.

${ }^{28}$ Там само, т. 1, с. 1030.

29 Л. І. Шевченко, О. І. Ніка, О. І. Хом'як, А. А. Дем'янюк, Новий словник іншомовних слів..., с. 377.

${ }^{30}$ Украӥнсько-англійський ілюстрований медичний словник Дорланда..., т. 1, с. 1031.

${ }^{31}$ Там само, т. 1, с. 1030.

${ }^{32}$ Там само, т. 1, с. 1029.

${ }^{33}$ Там само, т. 1, с. 1030.

34 Там само.

35 Tам само.

36 Tам само.

${ }^{37}$ Там само, т. 2, с. 1029-1030. 
вивчення механізмів збереження пози стояння; рентгенографія голови"з8; кефалометрія - “вимірювання голови градуйованим циркулем; в антропології: вимірювання черепа"39; медулярний - “1) такий, що стосується мозку; 2) такий, що стосується кісткового мозку; 3) такий, що стосується спинного мозку”. Ін. назва мієлоїдний ня кісткового мозку, довгастого мозку, мозкового шару" 4 . Незважаючи на полісемію того чи того слова, кожне зі значень стосується медичної термінології.

Серед опрацьованих термінів виявлено синонімію: медулярний - 1) “такий, що стосується мозку; 2) такий, що стосується кісткового мозку; 3) такий, що стосується спинного мозку". Ін. назва мієлоӥдний 42 ; менінгізм - “симптоми та ознаки подразнення мозкових оболонок, пов'язані із гострим гарячковим захворюванням чи дегідрацією без фактичного їхнього інфікування". Ін. назва псевдоменінгіт ${ }^{43}$; менінго-васкулярний - оболонково-судинний 44 ; менінгогематома - епідуральна гематома ${ }^{45}$; менінгорагія — "кровотеча 3 оболонок головного чи спинного мозку”. Див. субарахноӥдальний крововилив і субдуральний крововилив. Ін. назва менінгорея ${ }^{46}$. П. Штепа пропонує національний відповідник до слова менінгіт - мізкозапал ${ }^{47}$. Синонімія простежується як серед термінів чужомовного походження, так і в українських відповідниках. Як зазначає I. Кочан, „синонімія й варіанти в термінології явище не бажане, але цілком реальне, його існування сприяє унормуванню фахової мови, бо із часом одна з одиниць починає домінувати, відсікаючи іншу на другий план"48.

Отже, слова із соматичним компонентами кефал-, медул(о)-, менін-, менінг(о)- позначають: процеси; назви захворювань; приналежність до органа, його захворювання або дії щодо нього; види. Опрацьовані терміни в основному відповідають переліченим вище ознакам термінологічної норми, оскільки співвідносяться з поняттями, що входять до медичної терміносистеми, мають чіткі дефініції в словниках, є стилістично нейтральними, однак окремі з них все-таки не відповідають вимогам однозначності (наведено полісемію таких лексем) та синонімії (наведено синоніми як до слів іншомовного походження, так і їхні українські відповідники). Зазначене можна пояснити тим, що ці вимоги швидше бажані, ніж реальні. Полісемія свідчить про розвиток слова-терміна, але iз часом може одне зі значень отримати нову номінацію.

Компоненти кефал-, медул(о)-, менін-, менінг(o)- не поєднуються безпосередньо з українськими основами та коренями. Більшість компонентів - це компоненти іншомовного походження, що мають конкретне лексичне значення, яке зберігається повністю або частково в похідних словах.

Із кінця XX ст. і дотепер триває інтенсивне опрацювання медичної термінології, оскільки простежуємо іiі постійну розбудову. Медицина не стоїть на

\footnotetext{
${ }^{38}$ Н.П.Литвиненко, Н.В. Місник, Тлумачний словникмедичних термінів..., с. 314.

39 Там само.

40 Там само.

41 Там само.

42 Украйнсько-англійський ілюстрований медичний словник Дорланда..,, т. 1, с. 1018.

43 Там само, с. 1029.

${ }^{44}$ Там само, т. 1, c. 1030.

45 Там само.

46 Там само.

${ }^{47}$ П. Ш теп а, Словник чужослів, Торонто 1977, с. 182.

${ }^{48}$ I. Кочан, Варіанти і синоніми термінів з міжнародними компонентами, [в:] Електронний ресурс: http://vlp.com.ua/files/03_38.pdf (22.02.2018).
} 
місці, 3'являються новітні методи діагностики хвороб, нетрадиційні методи їхнього лікування, тому й виникає потреба у творенні нових термінів, а також в уніфікації їхньої граматичної структури. Медичне термінотворення є спільною справою і медиків, і мовознавців. Необхідно працювати над створенням єдиної медичної номенклатури.

\section{Список використаної літератури}

Кочан I., Варіанти і синоніми термінів з міжнародними компонентами, [в:] Електронний ресурс: http://vlp.com.ua/files/03_38.pdf (22.02.2018).

Кочан I. М., Терміни з міжнародними соматичними компонентами в сучасній українській мові, [в:] „Мова. Культура. Взаєморозуміння”, зб. наук. праць, за наук. ред. Т. Космеди, Дрогобич 2012, вип. 2, с. 169-179.

Кочан І. М., Українська наукова лексика: міжнародні компоненти в термінологіӥ, навч. посіб., Київ 2013.

Кочукова Н. І., Терміни з компонентом нео- в украӥнській науковій мові, [в:] „Наукові записки Національного університету «Острозька академія», сер. «Філологічна»”, 2014, вип. 49, с. 55-57.

Литвиненко Н. П., Місник Н. В., Тлумачний словник медичних термінів: російською, латинською та українською мовами, Київ 2010.

Луковенко Т. О., Українська гомеопатична лексика, автореф. дис. ... канд. філол. наук, Донецьк 2011.

Навчук Г. В., Ткач А. В., Украӥнська медична термінологія на сучасному етапі: проблеми впорядкування, [в:] Електронний ресурс: https://www.bsmu.edu.ua/files/BMV/ BMV-2010-14-04(56)/BMV-2010-14-04(56)-163.pdf (12.02.2018).

Стрижаковська О. С., Назви хвороб у буковинських говірках, автореф. дис. ... канд. філол. наук, Івано-Франківськ 2011.

Тихоша В. І., Структурно-семантичні особливості медичних термінів украӥнської мови, [в:] „Філологічні науки”, зб. наук. праць, Херсон 2003, вип. 20, с. 100-104.

Украӥнсько-англійський ілюстрований медичний словник Дорланда (перев. 30-го, америк. вид-ня), у 2 томах, Львів 2007.

Шевченко Л. І., Ніка О. І., Хом’як О. І., Дем'янюк А. А., Новий словник іншомовних слів, за ред. Л. І. Шевченко, Київ 2008.

Штепа П., Словник чужослів, Торонто 1977.

\section{Spysok vykorystanoi literatury [References]}

Kochan I., Varianty i synonimy terminiv z mizhnarodnymy komponentamy [Variants and Synonyms of Terms with International Components], [v:] Elektronnyi resurs: http://vlp.com. ua/files/03 38.pdf (22.02.2018).

Kochan I. M., Terminy z mizhnarodnymy somatychnymy komponentany v suchasnii ukrainskii movi [Terms with International Somatic Components in Modern Ukrainian], [v:] „Mova. Kultura. Vzaiemorozuminnia", zb. nauk. prats, za nauk. red. T. Kosmedy, Drohobych 2012, vyp. 2, s. 169-179.

Kochan I. M., Ukrainska naukova leksyka: mizhnarodni komponenty v terminolohii [Ukrainian Scientific Lexis: International Components in Terminology], navch. posib., Kyiv 2013.

Kochukova N. I., Terminy z komponentom neo- v ukrainskii naukovii movi [Terms with NeoComponent in Ukrainian Scientific Language], [v:] „Naukovi zapysky Natsionalnoho universytetu «Ostrozka akademiia», ser. «Filolohichna»", 2014, vyp. 49, s. 55-57.

Lytvynenko N. P., Misnyk N. V., Tlumachnyi slovnyk medychnykh terminiv: rosiiskoiu, latynskoiu ta ukrainskoiu movamy [Explanatory Dictionary of Medical Terms: in Russian, Latin and Ukrainian], Kyiv 2010. 
Lukovenko T. O., Ukrainska homeopatychna leksyka [Ukrainian Homeopathy Lexis], avtoref. dys. ... kand. filol. nauk, Donetsk 2011.

Navchuk H. V., Tkach A. V., Ukrainska medychna terminolohiia na suchasnomu etapi: problemy vporiadkuvannia [Ukrainian Medical Terminology at Modern Stage: Problems of Compiling], [v:] Elektronnyi resurs: https://www.bsmu.edu.ua/files/BMV/BMV2010-14-04(56)/BMV-2010-14-04(56)-163.pdf (12.02.2018).

Stryzhakovska O. S., Nazvy khvorob u bukovynskykh hovirkakh [Names of Diseases in Bukovyna Dialects], avtoref. dys. ... kand. filol. nauk, Ivano-Frankivsk 2011.

Tykhosha V. I., Strukturno-semantychni osoblyvosti medychnykh terminiv ukrainskoi movy [Structural, Semantic Peculiarities of Medical Terms in Ukrainian], [v:] „Filolohichni nauky", zb. nauk. prats, Kherson 2003, vyp. 20, s. 100-104.

Ukrainsko-anhliiskyi iliustrovanyi medychnyi slovnyk Dorlanda [Ukrainian-English Medical Dictionary with Illustrations... Compiled by Dorland] (perev. 30-ho, ameryk. vyd-nia), u 2 tomakh., Lviv 2007.

Shevchenko L. I., Nika O. I., Khomiak O. I., Demianiuk A. A., Novyi slovnyk inshomovnykh sliv [New Dictionary of Foreign Words], za red. L. I. Shevchenko, Kyiv 2008.

Shtepa P., Slovnyk chuzhosliv [Dictionary of Foreign Words], Toronto 1977. 